East African Medical Journal Vol. 80 No. 7 July 2003

PUERPERAL COMPLICATIONS OF EPISIOTOMIES AT AHMADU BELLO UNIVERSITY TEACHING HOSPITAL ZARIA, NIGERIA

S. T. Sule MBBS, MPH, FWACS, Lecturer I/Consultant, S. O. Shittu, MBBS, FWACS, Dip. Rep. Health (Liv), FICS, Senior Lecturer/Consultant, Department of Obstetrics and Gynaecology, Ahmadu Bello University Teaching Hospital, Zaria, Nigeria

Request for reprints to: Dr. S. T. Sule, Department of Obstetrics and Gynaecology, Ahmadu Bello University Teaching Hospital, Zaria, Nigeria

\title{
PUERPERAL COMPLICATIONS OF EPISIOTOMIES AT AHMADU BELLO UNIVERSITY TEACHING HOSPITAL, ZARIA, NIGERIA
}

\author{
S. T. SULE and S. O. SHITTU
}

\begin{abstract}
Objectives: To establish the epidemiological variables associated with episiotomies and their puerperal complications at Ahmadu Bello University Teaching Hospital Zaria, in order to institute appropriate management including preventive measures.

Design: A prospective cohort study.

Setting: Ahmadu cello University Teaching Hospital, Zaria, Nigeria.

Methods: A cohort of all consecutive patients that underwent vaginal deliveries during a 12week period were followed up for six weeks in order to determine the distribution and determinants of episiotomy and its complications.

Results: The episiotomy rate was $35.6 \%$ of all vaginal deliveries. Episiotomies were significantly associated with primigravidity being performed in $88.5 \%$ of all primigravidae. The mean delivery-repair interval was 60.5 minutes. The most common puerperal complication of episiotomies was perineal pain that lasted an average of 5.5 days. Other complications included asymmetry $(32.9 \%)$, infection $(23.7 \%)$, partial dehiscence $(14.5 \%)$, skin tags (7.9\%), haemorrhage $(5.3 \%)$ and extension of the incision $(1.3 \%)$. The complications were not significantly associated with any potential risk factor.

Conclusion: In view of the very high episiotomy rate among primigravidae, it is recommended that the episiotomy rate among primigravidae be reduced by re-acquainting accoucheurs with the indications for episiotomy. Attention needs to be given to adequate pain relief for all women who have had an episiotomy and the delivery-repair interval in this unit should be reduced by provision of materials for episiotomy repair in the delivery suite.
\end{abstract}

\section{INTRODUCTION}

Episiotomy is one of the most common operations performed on women, (1-3), ranging between $30 \%$ of deliveries in Europe and $62.5 \%$ in the United States of America $(1,3)$. Episiotomies are more common in hospital deliveries and in primigravidae $(3,4)$. In some countries, such as Argentina, it is routinely performed on all nulliparous and primiparous births (1). The World Health Organisation recommends an episiotomy rate of $10 \%$ for all normal deliveries (5). In this centre, the policy of the Department of Obstetrics and Gynaecology is for selective use of episiotomy. Episiotomies are prescribed electively for women who have past history of lower genital tract surgeries and for women who require assisted vaginal deliveries. For other women in labour, episiotomies may be given on emergency basis when there is presumed imminent perineal tear.

There are two types of episiotoies, midline and mediolateral. Midline episiotomies are more commonly used in the United States of America while mediolateral episiotomies are preferred in the United Kingdom (6). In this centre, mediolateral episiotomies are preferred most likely as a result of the strong British influence in Nigeria.
The perceived advantages of episiotomies include reduction in the incidence of perineal lacerations especially third degree perineal tears. They are easier to repair, and heal better than lacerations, being clean incisions. They are thought to preserve muscle relaxation of the pelvic floor and perineum leading to improved sexual function, and a reduced risk of faecal and/or urinary incontinence. Episiotomies are also thought to protect from intracranial haemorrhage especially when it is premature, and also reduce the likelyhood of shoulder dystocia. These beneficial effects are now being challenged as they are not backed by strong scientific evidence and more selective use of episiotomies is advocated $(2-4,7,8)$.

Complications of episiotomies include accidental extension into the anal sphincter or rectum, damage to the Bartholin's gland, unsatisfactory anatomic results such as skin tags, asymmetry or excessive narrowing of the introitus, vaginal prolapse, recto-vaginal fistula and fistula in ano $(3,7,9-12)$. Other complications include pain and oedema $(3,7)$, increased blood loss, haematoma, infection and dehiscence (3). Psychological trauma and dyspareunia may also occur and may last for many months after delivery $(1-4,13)$, although the role of episiotomies in the causation of dyspareunia in the long term is not clear (8). 
Rare complications include endometriosis in the episiotomy scar, non-healing of the episiotomy, lidocaine intoxication of the neonate, and a broken needle lost in the perineal tissue (3).

Risk factors that have been suggested for development of complications of episiotomies include the skill of the operator which may account for cutting too laterally and damaging other structures such as the Bartholin's gland, or making a ragged incision which may be difficult to repair and may not heal properly. The technique of repair and the type of suture used may also affect the outcome of the episiotomy repair. Continuous subcuticular stitches have been found to be associated with fewer problems than the interrupted transcutaneous stitches, and polyglactin or polyglycolic acid sutures have been found to be associated with less perineal pain than other sutures. Other factors include perineal contamination and delayed repair of the episiotomy, both of which increase the risk of infection (3).

Although most of the complications of episiotomies are usually not life threatening, they are not uncommon and constitute an important cause of maternal morbidity particularly in the puerperium. It is therefore, important to identify the distribution and determinants of such complications, with a view to preventing their occurrence or treating them appropriately where they have already occurred.

The aim of this study was to establish the distribution and determinants of the episiotomies and their puerperal complications, at Ahmadu Bello University Teaching Hospital Zaria, with a view to instituting appropriate management and prevention measures. Specific objectives were to determine the rate, distribution of episiotomies, the incidence of complications and their risk factors, and recommend possible measures for preventing such complications.

\section{MATERIALS AND METHODS}

This was a prospective cohort study carried out in the Department of Obstetrics and Gynaecology, Ahmadu Bello University Teaching Hospital, Zaria. The subjects were recruited at the delivery suite and included all consecutive patients who had vaginal births during a 12-week period from August 19th 2000 to November 11th 2000, and consented to being included in the study. Patients who delivered before arrival in the delivery suite and those who had perineal tears or operative abdominal births were excluded.

Bio-social and medical information were recorded for each patient at the delivery suite before discharge. Each patient was reviewed one week and six weeks post-delivery. At each review, information about symptoms of possible complications of episiotomies was obtained from the patients and physical examination including perineal examination, was performed. Patients who had discharge from the episiotomy wound with or without tenderness were considered to have infected episiotomy sites and had wound swabs taken for microbiological examination. All patients had packed cell volume estimation and temperature recording on admission and at one week after delivery to detect anaemia and pyrexia. Patients who had complications were given the appropriate treatment.

Complications were compared among patients who had episiotomies and those who did not. Among patients who had episiotomies, possible risk factors were compared among those who had complications and those who did not. Statistical analyses included rates and comparative analyses, and were carried out using appropriate computer statistical software including MINITAB, SPSS, and EXCEL.

\section{RESULTS}

There were 274 deliveries during the study period. Of these, $26(9.5 \%)$ were caesarean births, one $(0.4 \%)$ was a laparotomy for uterine rupture, and 247 (90.2\%) were vaginal births. Twenty seven (10.9\%) of those who had vaginal births had perineal tears, 88 (35.6\%) had episiotomies, and $132(53.4 \%)$ had intact perineums,

The analyses were carried out on the 220 patients who had vaginal births without perineal tears. Of these, $40 \%$ had episiotomies while $60 \%$ did not $149(67.7 \%)$ of these patients came for follow-up and of these, 76 (51\%) were patients who had episiotomies during delivery. All the episiotomies were of the mediolateral type and given on emergency basis. All the episiotomies were sutured using interrupted transcutaneous stitches with chromic catgut $2 / 0$. The comparison of characteristics of patients who had episiotomies and those that did not is shown in Table 1.

Episiotomies were significantly associated with primigravidity. $78.4 \%$ of all those who had episiotomies were primigravidae and $88.5 \%$ of all primigravidae had episiotomies $(p=<0.0001)$. Episiotomies were also significantly associated with foetal breech and occipito posterior position $(\mathrm{p}=0.02)$, and instrumental and assisted breech deliveries $(p=0.009)$. The association of episiotomies with lower maternal age, longer first and second stages of labour and longer duration of rupture of foetal membranes became statistically insignificant (p-value $=0.09,0.3,0.3$ and 0.06, respectively), after controlling for parity. There was no significant association between episiotomy and gestational age at delivery $(p=0.2)$, foetal birth weight $(p=0.5)$, and number of foetuses $(p=0.2)$. The comparison of complications that occurred in patients that had episiotomies and those that did not is shown in Table 2. All the patients who had episiotomies had postpartum perineal pain lasting for 24 hours or more, as compared with only seven of those without episiotomies $(\mathrm{p}=<0.0001)$.

The minimum duration of perineal pain in patients who had episiotomies was three days $(7.9 \%)$ while the maximum duration was ten days $(9.2 \%)$. The minimum duration of analgesic therapy for perineal pain was three days $(18.4 \%)$ while the maximum was eight days (1.32\%). Only six patients had resumed coitus during the follow-up period, three of these had episiotomy at delivery while the rest did not. None of these patients reported having dyspareunia. 
Table 1

Characteristics of patients who had episiotomies compared to those with intact perineums

\begin{tabular}{|c|c|c|c|c|c|}
\hline Variable & Episiotomy & No episiotomy & $\begin{array}{l}\text { Difference in } \\
\text { means }\end{array}$ & T-value & P-value \\
\hline Age & 23.9 years $(4.4)$ & 28.5 years $(6)$ & 4.6 years $(-6,3.2)$ & -6.6 & $\begin{array}{l}<0.0001 \\
(0.002)\end{array}$ \\
\hline Gestational age & 274.8 days (11.5) & 272.9 days $(10.5)$ & 3.9 days $(-1.9,5.6)$ & 1 & $0.3(>1)$ \\
\hline $\begin{array}{l}\text { Duration of the first stage } \\
\text { of labour }\end{array}$ & 9.2 hours $(3.5)$ & 6.4 hours $(2.5)$ & $\begin{array}{l}2.8 \text { hours }(2, \\
3.7)\end{array}$ & 6.7 & $\begin{array}{l}<0.0001 \\
(0.002)\end{array}$ \\
\hline $\begin{array}{l}\text { Duration of the second } \\
\text { stage of labour }\end{array}$ & 33.7 minutes (17.4) & 22.9 minutes (11) & 10.8 minutes $(6.7,15)$ & 5.2 & $\begin{array}{l}<0.0001 \\
(0.002)\end{array}$ \\
\hline $\begin{array}{l}\text { Duration of rupture of } \\
\text { the foetal membranes }\end{array}$ & 11 hours $(16.1)$ & 4.1 hours (4.6) & 6.9 hours $(3.4,10.4)$ & 3.9 & $\begin{array}{l}0.0002 \\
(0.003)\end{array}$ \\
\hline $\begin{array}{l}\text { Estimated blood loss at } \\
\text { delivery }\end{array}$ & 252 millilitres (179) & $\begin{array}{l}217 \text { millilitres } \\
(200)\end{array}$ & $\begin{array}{l}35 \text { millilitres } \\
(-15,86)\end{array}$ & $(-1.4)$ & $0.2(>1)$ \\
\hline $\begin{array}{l}\text { APGAR score at the first } \\
\text { minute }\end{array}$ & $8.6(2.1)$ & $9.1(1.8)$ & $0.5(-1.1,0)$ & 2 & $0.05(0.8)$ \\
\hline $\begin{array}{l}\text { APGAR score at the fifth } \\
\text { minute }\end{array}$ & $9.2(1.8)$ & $9.5(1.6)$ & $0.3(-0.8,0.2)$ & -1.2 & $0.2(>1)$ \\
\hline Birth weight & 3066 grams (462) & 3073 grams (566) & 7 grams $(145,130)$ & -0.1 & $0.9(>1)$ \\
\hline
\end{tabular}

Key

Mean (standard deviation)

Difference in means (95\% confidence intervals)

$\mathrm{P}$-value (after Bonferroni correction)

Table 2

Comparison of complications among patients who had episiotomies and those who had intact perineums

\begin{tabular}{|c|c|c|c|c|c|}
\hline Variable & $\begin{array}{l}\text { Mean: } \\
\text { episiotomy } \\
\text { (standard } \\
\text { deviation) }\end{array}$ & $\begin{array}{l}\text { Mean: no } \\
\text { episiotomy } \\
\text { (standard } \\
\text { deviation) }\end{array}$ & $\begin{array}{c}\text { Difference of } \\
\text { means }(95 \% \\
\text { confidence } \\
\text { intervals) }\end{array}$ & $\begin{array}{c}\mathrm{T} \\
\text { value }\end{array}$ & $\begin{array}{c}\text { P-value (after } \\
\text { Bonferroni } \\
\text { correction) }\end{array}$ \\
\hline Postpartum perineal pain & 5.5 days (1.9) & 1.1 days $(0.4)$ & 4.4 days $(3.8,4.9)$ & 6.7 & $<0.0001(0.003)$ \\
\hline Analgesic therapy for perineal pain & 4.8 days $(1.3)$ & 1.2 days $(0.5)$ & 3.6 days $(2.8,4.3)$ & 12 & $<0.0001(0.003)$ \\
\hline Resumption of coitus & 4.7 weeks $(0.6)$ & 4.3 weeks $(0.6)$ & 0.4 weeks $(-1,1.6)$ & 0.7 & $0.5(>1)$ \\
\hline
\end{tabular}

Other complications were present in 46 of the 76 patients who came for follow up $(60.5 \%)$ and some of these patients had more than one complication. These complications were not observed in patients who had intact perineums. Asymmetry occurred in 25 patients (32.9\%) and was detected at the second follow up visit at six weeks. It was not significantly associated with any other complication or any of the risk factors that were studied. Eighteen (23.7\%) patients had infection of the episiotomy wound and three $(16.7 \%)$ of these, the wound swab yielded no growth, contaminants in nine $(50 \%)$ patients, Staphylococcus aureus in four (22.2\%) patients, and Escherichia coli in two (11.1\%) patients. All cases of infection were detected at the first follow-up visit. Infection of the episiotomy wound was significantly associated with dehiscence $\left(\mathrm{X}^{2} 32.2, \mathrm{p}=\right.$ $<0.0001)$. Dehiscence of the wound occurred in 11 patients $(14.5 \%)$ and was partial involving only the skin in all the cases.

Other complications included skin tags, which occurred in six patients $(7.9 \%)$, and significant haemorrhage from the episiotomy site, which occurred in four patients $(5.3 \%)$. One patient $(1.3 \%)$ had extension of the episiotomy into the anterior fibres of the anal sphincter after a forceps delivery. These complications were not significantly associated with any of the potential risk factors that were studied.

The mean delivery-repair interval for patients who had an episiotomy was 60.5 minutes (range $=5$ to 600 minutes). Among patients who returned for follow up, the mean delivery-repair was 72.7 minutes for those who had complications and 55.2 minutes for those who did not have complications. The difference was not significant (Table 3). 
Table 3

Factors that may be associated with complications of episiotomies

\begin{tabular}{|c|c|c|c|c|c|}
\hline Variable & $\begin{array}{c}\text { Mean: } \\
\text { complication } \\
\text { (standard } \\
\text { deviation) }\end{array}$ & $\begin{array}{l}\text { Mean: no } \\
\text { complication } \\
\text { (standard } \\
\text { deviation) }\end{array}$ & $\begin{array}{c}\text { Difference of } \\
\text { means (95\% } \\
\text { confidence } \\
\text { intervals) }\end{array}$ & T-value & $\begin{array}{c}\text { P-value (after } \\
\text { Bonferroni } \\
\text { correction) }\end{array}$ \\
\hline Age & 24.3 days (4.7) & 22.7 years $(3.4)$ & $\begin{array}{c}1.6 \text { years } \\
(-3.37,0.31)\end{array}$ & 1.7 & $0.1(>1)$ \\
\hline Gestational age & 274 days $(9.5)$ & 277.4 days $(10)$ & $\begin{array}{l}3.4 \text { days } \\
(-2.2,8.9)\end{array}$ & 1.2 & $0.2(>1)$ \\
\hline First stage of labour & 9.5 hours $(3.7)$ & 9.3 hours $(3.6)$ & $\begin{array}{l}0.2 \text { hours } \\
(-1.9,1.5)\end{array}$ & 0.3 & $0.8(>1)$ \\
\hline Second stage of labour & $\begin{array}{l}34.3 \text { minutes } \\
(18.2)\end{array}$ & $\begin{array}{l}31 \text { minutes } \\
(15.1)\end{array}$ & $\begin{array}{l}3.3 \text { minutes } \\
(-11,4.3)\end{array}$ & 0.9 & $0.4(>1)$ \\
\hline Rupture of foetal membranes & 8.5 hours $(9.1)$ & $\begin{array}{c}10.3 \text { hours } \\
(14.5)\end{array}$ & $\begin{array}{l}1.8 \text { hours } \\
(-4.2,7.8)\end{array}$ & 0.6 & $0.6(>1)$ \\
\hline $\begin{array}{l}\text { Delivery-repair } \\
\text { interval }\end{array}$ & $\begin{array}{l}72.7 \text { minutes } \\
(97.8)\end{array}$ & $\begin{array}{c}55.2 \text { minutes } \\
(58.9)\end{array}$ & $\begin{array}{c}17.5 \text { minutes } \\
(-53,18)\end{array}$ & 1 & $0.3(>1)$ \\
\hline Estimated blood loss & $\begin{array}{c}268 \text { millilitres } \\
\text { (209) }\end{array}$ & $\begin{array}{c}228 \text { millilitres } \\
(156)\end{array}$ & $\begin{array}{c}40 \text { millilitres } \\
(-124,44)\end{array}$ & 1 & $0.3(>1)$ \\
\hline Birth weight & $\begin{array}{c}3071 \text { grams } \\
(491)\end{array}$ & $\begin{array}{l}3105 \text { grams } \\
(425)\end{array}$ & $\begin{array}{l}34 \text { grams } \\
(-177,246)\end{array}$ & 0.3 & $0.8(>1)$ \\
\hline Duration of sitz baths & 15.5 days $(4.4)$ & 11.9 days $(2.7)$ & $\begin{array}{l}3.6 \text { days } \\
(-5.2,2)\end{array}$ & -4.5 & $<0.0001(0.002)$ \\
\hline $\begin{array}{l}\text { Packed cell } \\
\text { volume on admission }\end{array}$ & $33.1 \%(2.8)$ & $33.7 \%(2.6)$ & $\begin{array}{c}0.6 \%(-0.7 \\
1.8)\end{array}$ & 0.9 & $0.4(>1)$ \\
\hline Temperature on admission & $36.7^{\circ} \mathrm{C}(0.5)$ & $36.6^{\circ} \mathrm{C}(0.4)$ & $0.1(-0.3,0.1)$ & 1 & $0.4(>1)$ \\
\hline
\end{tabular}

Table 3 shows the possible associated factors for complications of episiotomies that were analysed in this study. The only significant association was with the duration of sitz baths, which was longer for patients who had complications. The development of episiotomy complications was not significantly associated with parity, booking status, education, medical disorders, previous episiotomy or perineal tear, foetal presentation or position, mode of delivery, delivery position, delivery-repair interval, antibiotic therapy, or the operator who performed or repaired the episiotomy ( $p>0.05$ in each case).

\section{DISCUSSION}

The episiotomy rate in this centre was found to be $35.6 \%$ of all vaginal births, which is lower than the rate $(46.6 \%)$ reported from another centre in Nigeria, (14) but is similar to rates reported from other parts of the world $(1,15)$. The majority $(<70 \%)$ of those who had episiotomies were primigravidae among whom the episiotomy rate was $88.5 \%$. This is similar to the findings reported from other centres $(4,7,14)$, especially where a liberal policy on episiotomies is adopted and may reflect a belief that episiotomy is beneficial for all first births. The significant associations with lower maternal age, longer first and second stages of labour, and longer duration of rupture of the foetal membranes, which became insignificant after controlling for parity, further emphasise the association with lower parity. The episiotomy rate among primigravidae is much lower when a more restrictive policy in episiotomies is adopted (4), and this can be achieved in this centre by increasing the awareness of the indications for episiotomy among accoucheurs.

A significant association of episiotomies with the mode of delivery and foetal malposition/malpresentation is not unexpected as it is the routine in this centre to perform episiotomies during instrumental and difficult deliveries, as is the practice in other centres $(14,16)$.

The most common complication of episiotomies was postpartum perineal pain lasting for 24 hours or more, which was present in all women who had episiotomies during delivery as compared to only $9.6 \%$ of women who had intact perineums. The mean duration of perineal pain in women who had episiotomies (5.5 days) was significantly longer than it was in women without episiotomies (1.1 days). This finding is similar to what has been reported previously $(4,7)$, and is not unexpected as episiotomy is an injury, but it calls for routine attention to pain relief. Postpartum perineal pain requiring analgesia may continue for up to ten days after delivery in $2-3 \%$ of women who have had episiotomies $(3,4)$. In this study, the mean duration of analgesic therapy for perineal pain was 4.8 days in women who had episiotomies, and only one patient $(1.32 \%)$, required analgesia for perineal pain for eight days. It has been reported that diclofenac rectal suppositories administered at the time of repair of perineal injury including episiotomies, provides effective analgesia that may 
continue for up to three days postpartum (17). Assessment of the role of diclofenac in minimising post-episiotomy pain is required in this environment.

There was no association between perineal status and resumption of coitus in this study probably as a result of the fact that very few women had resumed coitus during the follow up period. This is most likely due to the cultural practice of postpartum abstinence, especially in the first six weeks after delivery in this environment.

Unsatisfactory anatomical results including asymmetry and skin tags were present in $40.8 \%$ of women who had episiotomy during delivery, in keeping with what has been previously reported (3). However, they were not a cause for concern in all the patients except those who had skin tags. All the women were properly counselled on the cause of the problem and none requested correction of the defect after counselling. This complication was not associated with any of the risk factors assessed in this study. Continuous subcuticular stitches, which are not used routinely in this centre, have been found to be associated with better healing than interrupted transcutaneous stitches (3). A randomised controlled study comparing the two methods would be of benefit in patient management in this environment.

Infection of the episiotomy wound was observed in $23.7 \%$ of the patients and was significantly associated with partial dehiscence. None of these cases required resuturing of the wound. Wound swab cultures yielded contaminants in $50 \%$ of the women who had infection, no organism was cultured in $16.7 \%$, while $33.3 \%$ of these women had positive cultures (Staphylococcus aureus and Escherichia coli). These results are not surprising, as it is difficult to actually determine the causative organism in episiotomy wound infections due to contamination from the bowel (3), although culture results may be positive.

Infection appeared to be associated with longer delivery-repair interval although the association was not statistically significant. An association between infection and delayed delivery-repair interval has been reported previously (3). Delivery-repair interval was unnecessarily long in this study with a mean of 60.5 minutes and this is mainly due to unavailability of required materials for immediate repair, such as, sutures or xylocaine, in the hospital. Patients' relations have to purchase these items from outside the hospital resulting in unnecessary delays. Infection also appeared to be associated with increased blood loss at delivery although this association was also not statistically significant. This may be as a result of anaemia, which increases susceptibility to infections. This requires further study using more precise measurements of blood loss. All cases of infection were treated with antibiotics and continued sitz baths, thus accounting for the significant association between infection and prolonged sitz baths.

Four patients $(5.3 \%)$ had primary postpartum haemorrhage resulting from the episiotomy but this complication was not associated with any of the risk factors that were assessed in this study. One of these patients had extension of the episiotomy into the anterior fibres of the anal sphincter after forceps delivery, which has been reported to be associated with a higher risk of extension of episiotomies into the anal sphincter and mucosa $(3,16)$. However, mediolateral episiotomies, which were used in this study, are associated with lower risk of extension into the anal sphincter as compared to midline episiotomies $(3,6,18)$. The risk of extension into the anal sphincter has also been found to be higher when delivery is conducted with the aid of stirrups (19), as was the case with the patient who had this complication in this study. This is thought to be as a result of the increased perineal tension when stirrups are used.

The high complication rate of $60.5 \%$ may have been due to the poor follow up rate, as the complication may have been the motivating factor for attending the postnatal clinic, resulting in a falsely high rate. However, there is a need for prophylactic measures, such as ensuring minimal delay between delivery and episiotomy repair. This can be achieved by providing all the required materials for episiotomy repair in the labour ward at all times.

Episiotomy may also be associated with an increased risk of vertical transmission of the Human Immunodeficiency Virus (HIV) (20), and this possibility increases the need for re-emphasising the selective policy on episiotomy especially as the HIV status of most patients in this environment is unknown.

\section{ACKNOWLEDGEMENTS}

To the patients and staff of the Department of Obstetrics and Gynaecology, Ahmadu Bello University Teaching Hospital, Zaria, for making this study possible.

\section{REFERENCES}

1. Carroli, G. and Belizan, J. Episiotomy for vaginal birth (Cochrane Review). In: The Cochrane Library. Oxford Update Software. 2000; 1.

2. World Health Organisation, Standards of Midwifery Practice for Safe Motherhood. Volume 3: Notes on Advances in Practice. World Health Organisation Regional Publication. SEARO. 1999; 38:35-36.

3. Thacker, S.B. and Banta, H.D. Benefits and Risks of episiotomy: An interpretative review of the English Language Literature, 1860-1980. Obs. and Gyna. Survey 1983; 38:322-238.

4. Sleep, J., Grant, A., Garcia, J., Elbourne, D., Spencer, J. and Chalmers, I. West Berkshire perineal management trial. Brit. Med. J. 1984; 289:587-590.

5. Johanson, R. Obstetric Procedures. In Edmonds D.K., editor. Dewhurst's Textbook of Obstetrics and Gynaecology for Postgraduates. Oxford, Blackwell Science 1999; 308-329.

6. Coats, P.M., Chan, K.K., Wilkins, M. and Beard, R.J. A comparison between midline and mediolateral episiotomies. Brit. J. Obst. Gynae. 1980; 87:408-412.

7. Harrison, R.F., Brennan, M., North, P.M., Reed, J.V. and Wickham, E.A. Is routine episiotomy necessary? Brit. Med. J. 1984; 288: 1971-1975.

8. Sleep, J. and Grant, A. West Berkshire perineal management trial: three year follow up. Brit. Med. J. 1987; 295:749-751.

9. Howard, D., DeLancey, J.O., and Burney, R.E. Fistula-in-and after episiotomy. Obst. and Gynae. 1999; 93:800-802. 
10. Barranger, E., Haddad, B. and Paniel, B.J. Fistula-in-ano as a rare complication of mediolateral episiotomy: report of three cases. Amer. J. Obst. and Gynae. 2000; 182:733-734.

11. Signorello, L.B., Harlow, B.L., Chekos, A.K. and Repke, J.T. Midline episiotomy and anal incontinence: retrospective cohort study. Brit. Med. J. 2000. 320:86-90.

12. Zetterstrom, J., Lopez, A., Anzen, B.et al. Anal sphincter tears at vaginal delivery: risk factors and clinical outcome of primary repair. Obst. and Gynae. 1999; 94:21-28.

13. Russell, J.K. Episiotomy. Brit. Med. J. 1982; 284: 220.

14. Otoide, V.O., Ogbonmwan, S.M. and Okonofua, F.E. Episiotomy in Nigeria. Inter. J. Gynae. and Obste. 2000; 68:13-17.

15. Williams, F.L., du V Florey, C., Mires, G.J. and Ogston, S.A. Episiotomy and perineal tears in low- risk U.K. primigravidae. J. Public Health Med. 1998; 20:422-427.

16. Ogunniyi, S.O., Sanusi, Y.O. and Faleyimu, B.L. Forceps delivery at Wesley Guild Hospital, llesa, Nigeria: a ten year review. West Afr. J. Med. 1997; 16:30-35.

17. Searles, J.A. and Pring, D.W. Effective analgesia following perineal injury during childbirth: a place for controlled trial of prophylactic rectal diclofenac. Brit. J. Obste. and Gynae. 1998; 105:627-631.

18. Poen, A.C., Felt-Bersma, R.J., Dekker, G.A. et al. Third degree obstetric perineal tears: risk factors and the preventive role of mediolateral episiotomy. Brit. J. Obs. and Gynae. 1997; 104:563-566.

19. Borgatta, L., Piening, S.L. and Cohen, W.R. Association of episiotomy and delivery position with deep perineal laceration during spontaneous delivery in nulliparous women. Amer. J. Obst. and Gynae. 1989; 160:294-297.

20. Liljestrand, J. Episiotomy policies in vaginal births (Reproductive Health Library Commentary). In: The Cochrane Library. 2000; 1.

\section{EAMJ INTERNET ADDRESS}

The East African Medical J ournal is now available online as well as in print. Subscribers and readers interested in viewing the Internet version may access it using the following address: http:/ / www.biolineorg.br

The Online version is distributed by the non-profit service; Bioline Publications, a South/North partnership whose aim is to facilitate global access to bioscience and medical research publications, with emphasis on journals published in the developing world.

Subscription to the online version may be made by completing the Registration form available from the Bioline home page (http:/ / www.biolineorg.br). Readers may take out an annual subscription or purchase single documents. Abstracts are available without registration and free of charge. 